Provided for non-commercial research and education use. Not for reproduction, distribution or commercial use.

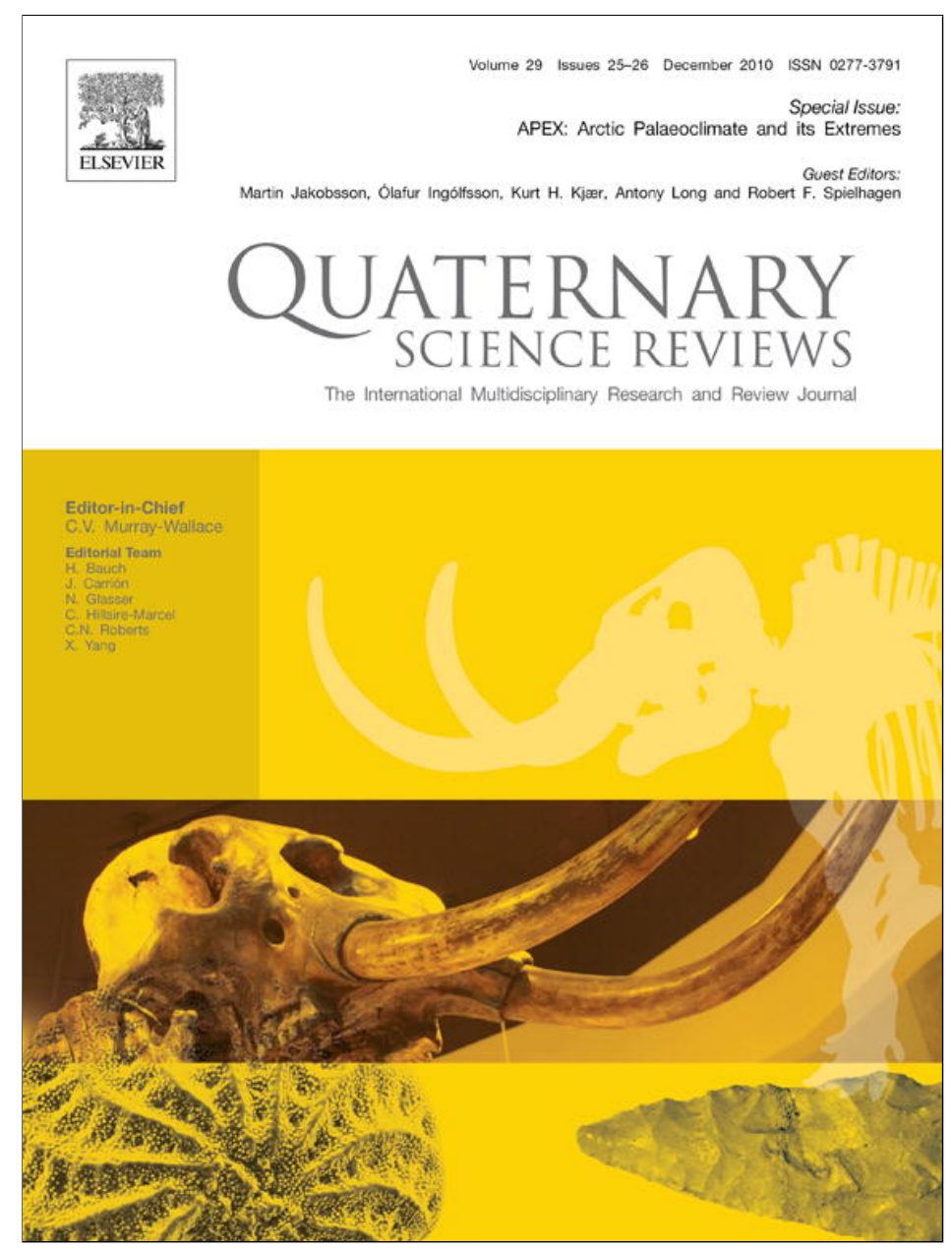

This article appeared in a journal published by Elsevier. The attached copy is furnished to the author for internal non-commercial research and education use, including for instruction at the authors institution and sharing with colleagues.

Other uses, including reproduction and distribution, or selling or licensing copies, or posting to personal, institutional or third party websites are prohibited.

In most cases authors are permitted to post their version of the article (e.g. in Word or Tex form) to their personal website or institutional repository. Authors requiring further information regarding Elsevier's archiving and manuscript policies are encouraged to visit:

http://www.elsevier.com/copyright 


\title{
An Arctic Ocean ice shelf during MIS 6 constrained by new geophysical and geological data
}

\author{
Martin Jakobsson ${ }^{\mathrm{a}, *}$, Johan Nilsson ${ }^{\mathrm{b}}$, Matthew O'Regan ${ }^{\mathrm{a}}$, Jan Backman ${ }^{\mathrm{a}}$, Ludvig Löwemark ${ }^{\mathrm{a}}$, \\ Julian A. Dowdeswell ${ }^{\mathrm{c}}$, Larry Mayer ${ }^{\mathrm{d}}$, Leonid Polyak ${ }^{\mathrm{e}}$, Florence Colleoni ${ }^{\mathrm{a}}$, f , Leif G. Anderson ${ }^{\mathrm{g}}$, \\ Göran Björk ${ }^{\mathrm{h}}$, Dennis Darby ${ }^{\mathrm{i}}$, Björn Eriksson ${ }^{\mathrm{a}}$, Daniela Hanslik ${ }^{\mathrm{a}}$, Benjamin Hell ${ }^{\mathrm{a}}$, \\ Christian Marcussen ${ }^{\mathrm{j}}$, Emma Sellén ${ }^{\mathrm{a}}$, Åsa Wallin ${ }^{\mathrm{a}}$ \\ ${ }^{a}$ Department of Geological Sciences, Stockholm University, Sweden \\ ${ }^{\mathrm{b}}$ Department of Meteorology, Stockholm University, Sweden \\ ${ }^{\mathrm{c}}$ Scott Polar Research Institute, University of Cambridge, UK \\ ${ }^{\mathrm{d}}$ Center for Coastal and Ocean Mapping, University of New Hampshire, USA \\ ${ }^{\mathrm{e}}$ Byrd Polar Research Center, Ohio State University, Ohio, USA \\ ${ }^{\mathrm{f}}$ Laboratoire de Glaciologie et Geophysique de l'Environnement, UJF, CNRS, France \\ ${ }^{g}$ Department of Chemistry, University of Gothenburg, Gothenburg, Sweden \\ ${ }^{\mathrm{h}}$ Earth Sciences Center, University of Gothenburg, Gothenburg, Sweden \\ ${ }^{i}$ Department of Ocean, Earth, E Atmospheric Sciences, Old Dominion University, Norfolk, USA \\ ${ }^{\mathrm{j}}$ Geological Survey of Denmark and Greenland (GEUS). Denmark
}

\section{A R T I C L E I N F O}

\section{Article history:}

Received 3 November 2009

Received in revised form

27 March 2010

Accepted 30 March 2010

\begin{abstract}
A B S T R A C T
The hypothesis of floating ice shelves covering the Arctic Ocean during glacial periods was developed in the 1970s. In its most extreme form, this theory involved a $1000 \mathrm{~m}$ thick continuous ice shelf covering the Arctic Ocean during Quaternary glacial maxima including the Last Glacial Maximum (LGM). While recent observations clearly demonstrate deep ice grounding events in the central Arctic Ocean, the ice shelf hypothesis has been difficult to evaluate due to a lack of information from key areas with severe sea ice conditions. Here we present new data from previously inaccessible, unmapped areas that constrain the spatial extent and timing of marine ice sheets during past glacials. These data include multibeam swath bathymetry and subbottom profiles portraying glaciogenic features on the Chukchi Borderland, southern Lomonosov Ridge north of Greenland, Morris Jesup Rise, and Yermak Plateau. Sediment cores from the mapped areas provide age constraints on the glaciogenic features. Combining these new geophysical and geological data with earlier results suggests that an especially extensive marine ice sheet complex, including an ice shelf, existed in the Amerasian Arctic Ocean during Marine Isotope Stage (MIS) 6. From a conceptual oceanographic model we speculate that the cold halocline of the Polar Surface Water may have extended to deeper water depths during MIS 6 inhibiting the warm Atlantic water from reaching the Amerasian Arctic Ocean and, thus, creating favorable conditions for ice shelf development. The hypothesis of a continuous $1000 \mathrm{~m}$ thick ice shelf is rejected because our mapping results show that several areas in the central Arctic Ocean substantially shallower than $1000 \mathrm{~m}$ water depth are free from glacial influence on the seafloor.
\end{abstract}

(c) 2010 Elsevier Ltd. All rights reserved.

\section{Introduction}

The idea of an Arctic Ocean ice shelf grew from Mercer's (1970) geographic comparison between the Eurasian Arctic Ocean and West Antarctica. Located close to the Earth's north and south poles, both regions host large continental shelf areas with water depths of some hundreds of meters. Portions of the West Antarctic

\footnotetext{
* Corresponding author. Tel.: +468164719.

E-mail address: martin.jakobsson@geo.su.se (M. Jakobsson).
}

continental shelf are today occupied by the West Antarctic Ice Sheet (WAIS), while there is no equivalent ice sheet in today's Eurasian Arctic (i.e. in the Barents, Kara and Laptev seas). The WAIS is marine-based, implying that its base is grounded well below sea level and that it flows, through systems of large ice streams, into floating ice shelves (Bentley, 1987; Anderson, 1999). The Ross Ice Shelf covers $511,680 \mathrm{~km}^{2}$ and the Filchner-Ronne Ice Shelf extends over $439,920 \mathrm{~km}^{2}$ (British Antarctic Survey, 2005). Together these two large ice shelves occupy an area corresponding to ca $21 \%$ of the deep central Arctic Ocean area beyond the shallow fringing shelves. 
Mercer's hypothesis was further developed by Hughes et al. (1977) to involve a continuous $1000 \mathrm{~m}$ thick ice shelf covering the Arctic Ocean that, together with surrounding grounded marine and terrestrial ice sheets, behaved as a single dynamic Arctic Ice Sheet during the LGM. In comparison, the mean thickness of the Antarctic ice shelves is estimated to be $440 \mathrm{~m}$, although thicknesses $>1000 \mathrm{~m}$ can be found near the grounding lines (Lythe et al., 2001). Grosswald and Hughes (2008) further refined the Arctic Ocean ice shelf theory and concluded that continuous $1000 \mathrm{~m}$ thick ice shelves were re-current elements during Pleistocene glacial maxima, including the LGM.

The present Arctic Ocean circulation involves net inflow of Atlantic water with about $1-1.5 \mathrm{~Sv}\left(1 \mathrm{SV}=10^{6} \mathrm{~m}^{3} \mathrm{~s}^{-1}\right)$ through the Fram Strait and $>2$ Sv via the Barents Sea (Maslowski et al., 2004; Rudels, 1995). These two flow paths merge off the St Anna Trough to form a cyclonic circulation along the slopes of the Arctic continental margins (Fig. 1). Transporting heat and salt into both the Eurasian and Amerasian Basins, the Atlantic water occupies water depths below the cold halocline between about 200 and $600 \mathrm{~m}$ and has temperatures from 0 to $2{ }^{\circ} \mathrm{C}$. Therefore, the present
Arctic Ocean circulation regime efficiently inhibits the development of major ice shelves. Existing Arctic Ocean ice shelves are tiny in comparison to the Antarctic ones and are located, for example, on the shallow continental margin along northern Ellesmere Island and in some deep Russian Arctic fjords, out of reach of warm Atlantic water and supported by the prevailing onshore wind direction (Jeffries, 1986; Williams and Dowdeswell, 2001; Dowdeswell and Jeffries, in press).

Ocean circulation and water temperature underneath ice shelves are critical for the ice mass balance; basal accretion amounting to as much as $190 \mathrm{~m}$ of ice from the grounding line to the calving front is observed underneath the Amery Ice Shelf in eastern Antarctica (Fricker et al., 2001). On the other hand, warm water has been shown to protrude onto the Amundsen Sea continental shelf in West Antarctica, causing thinning of the floating margin of Pine Island Glacier (Walker et al., 2007; Wåhlin et al., in press). It seems clear that, in order to grow large and thick Antarctic-style ice shelves in the Arctic Ocean, the influx of Atlantic water must be shut down or restricted to deeper depths to prevent basal melting and allow accretion. The importance of ocean

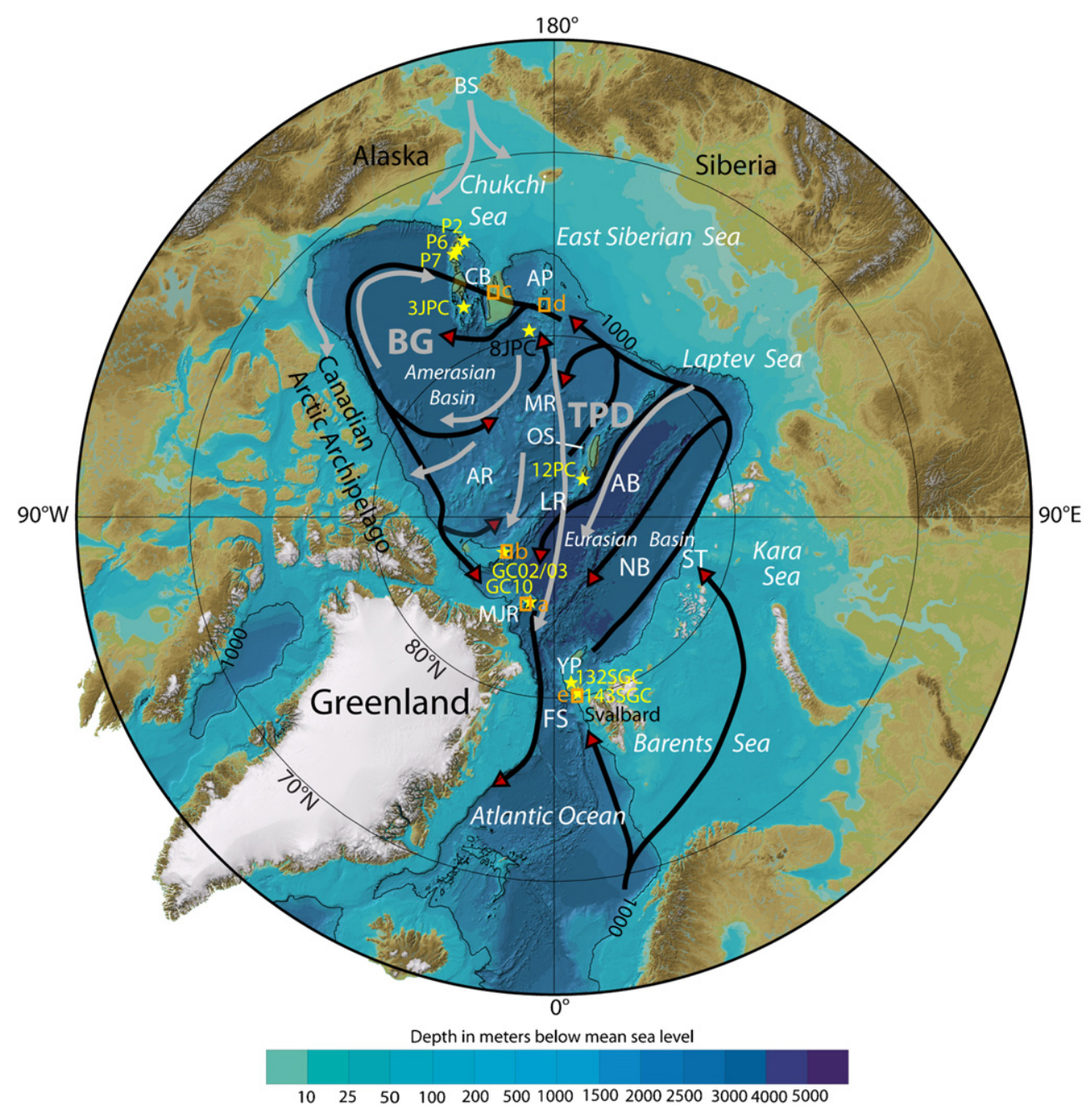

Fig. 1. Overview map of the Arctic Ocean with the circulation of surface (gray) and Atlantic waters (black) inferred from Rudels et al. (in press). Ice eroded areas mapped in previous studies are indicated by a green shading. The locations of the sediment cores included in this study are shown by yellow filled stars along with abbreviations of their station ids: P2, P1-92AR-P2; P6, P1-92AR-P6; P7, P1-92AR-P7; 3JPC, HLY0503-3JPC; 8JPC, HLY0503-8JPC; 12PC, 96/12-1PC; GC02, LOMROG07-GC-002; GC03, LOMROG07-GC-003; GC10, LOMROG07-GC-10; 143SGC, YMER-143SGC; 132SGC, YMER-132SGC. The $1000 \mathrm{~m}$ isobaths is shown from Version 2.0 of the International Bathymetric Chart of the Arctic Ocean (IBCAO) (Jakobsson et al., 2008a). The locations of detailed maps a-e shown in Fig. 2 are marked by orange boxes. Abbreviations of submarine features written with white capital letters: AB, Amundsen Basin; AR, Alpha Ridge; Arlis Plateau; BS, Bering Strait; CB, Chukchi Borderland; FS, Fram Strait; LR, Lomonosov Ridge; MJR, Morris Jesup Rise; MR, Mendeleev Ridge; NB, Nansen Basin; OS, Oden Spur; ST, St Anna Trough; YP, Yermak Plateau. 
temperature and circulation for the mass balance of floating ice was also discussed by Broecker (1975), who suggested that "Floating Ice Caps" in the Arctic Ocean could have developed if a critical steadystate sea ice thickness was reached. Broecker concluded that the limiting factor for the development of thick ice was the degree to which ice was exported from the Arctic through the Fram Strait.

The increased use of acoustic mapping tools from icebreakers and submarines over the past decades has allowed a systematic testing of the hypothesis of a $1000 \mathrm{~m}$ thick ice shelf in the Arctic Ocean, because the grounding of deep-drafted ice on bathymetric highs leaves diagnostic scars on the seafloor. Ice grounding is mapped down to $1000 \mathrm{~m}$ present water depth on the central Lomonosov Ridge as well as on the Chukchi Borderland and Yermak Plateau (Jakobsson, 1999; Polyak et al., 2001) (Fig. 1). However, the limited spatial distribution of previously collected seafloor morphological data did not provide conclusive evidence for or against a continuous floating ice shelf covering the entire Arctic Ocean (Jakobsson et al., 2008b).

Here, we present new multibeam bathymetry and subbottom profiles acquired during three expeditions from previously unsurveyed areas of the southern Lomonosov Ridge north of Greenland, the Morris Jesup Rise, the Yermak Plateau, and the Chukchi Borderland that, together with previously collected data, allow us to conclude that large ice shelves existed during some glaciations. These new data do not support the idea of a single large and coherent $1000 \mathrm{~m}$ thick ice shelf covering the entire Arctic Ocean. We propose that a large ice shelf complex was mainly restricted to the Amerasian part of the Arctic Ocean and that its existence depended on a different Atlantic water circulation. Dating of sediment cores from ice grounded areas suggests that the most prominent grounding events occurred during MIS 6.

\section{Materials and methods}

The geophysical data and sediment cores presented here were primarily collected during four expeditions: (1) the Lomonosov Ridge Off Greenland (LOMROG) 2007 when Swedish icebreaker Oden supported by the Russian nuclear icebreaker 50 Years of Victory were the first ever surface vessels operating on the Lomonosov Ridge north of Greenland (Jakobsson et al., 2008c); (2) the Healy-Oden Trans-Arctic Expedition (HOTRAX) 2005 when Oden and the US Coast Guard Cutter (USCGC) Healy together transected the central Arctic Ocean from the Bering Strait to the Fram Strait (Darby et al., 2009); (3) The HLY0905 expedition with USCGC Healy that included mapping of portions of the Chukchi Borderland; (4) The LOMROG II expedition 2009 with Oden (Fig. 1). Multibeam mapping during LOMROG 2007 was carried out using Oden's Kongsberg $12 \mathrm{kHz}$ EM120 $1 \times 1^{\circ}$ multibeam echo sounder and subbottom profiling with the integrated chirp sonar SBP120 $3^{\circ}$ operating in a frequency range of $2.5-7 \mathrm{kHz}$. This multibeam system was upgraded to Kongsberg's EM122 prior to the LOMROG II expedition. USCGC Healy has a $12 \mathrm{kHz}$ Seabeam 2112 multibeam and a Knudsen chirp sonar that were continuously operated during the HOTRAX 2005 and HLY0905 expeditions.

The sediment cores included in this study were selected in order to provide age information for the mapped ice grounding events. In addition to cores from LOMROG 2007, we have analyzed two cores from the Yermak Plateau retrieved during the Swedish YMER 1980 expedition (Boström and Thiede, 1984). Samples analyzed for nannofossils were prepared from unprocessed sediment as smear slides and examined using a light microscope at $1250 \times$ magnification. Nannofossils were counted in 50 fields of view following methods described by Backman and Shackleton (1983).

Vertical X-radiographic images of the sediment in three LOMROG 2007 cores were used to study details of the sedimentary structures. Radiographs were produced following standard procedures (Löwemark and Werner, 2001). First, plastic boxes $9.5 \times 6.5 \mathrm{~cm}$ large and $0.7 \mathrm{~cm}$ thick were pushed into the sediment, and then cut out using a nylon string. The sediment slabs were put in vacuum sealed plastic bags, placed directly on an X-ray film and then exposed at $55 \mathrm{kV}, 3 \mathrm{~mA}$ for $3 \mathrm{~min}$ at the Department of Geosciences at the University of Bremen.

\section{Results}

\subsection{Geophysical mapping}

Along with the geophysical mapping data from LOMROG 2007, HOTRAX 2005 and HLY0905, we also include previously published results in this section in order to provide the circum Arctic Ocean view of existing data with relevance for the glacial history, in particular concerning the existence of marine ice sheets. On the Morris Jesup Rise, which protrudes from the northern Greenland continental margin (Fig. 1), traces of ice grounding in $<1000 \mathrm{~m}$ water depths were previously postulated from subbottom profiles (Spielhagen et al., 2004). Our multibeam data reveal iceberg plowmarks down to $1045 \mathrm{~m}$ present water depth (Fig. 2a); to our knowledge the deepest iceberg-keel scour mapped in the central Arctic Ocean. The deepest keeled icebergs plowing the seafloor arrived from the direction of the southern Lomonosov Ridge area (Fig. 1). Morphological evidence shows that some of the thickest icebergs plowed into the northwestern edge of the Morris Jesup Rise before scouring across its crest and eventually drifting towards the Fram Strait. The shallowest part of the surveyed area, reaching $940 \mathrm{~m}$ water depth, shows no evidence for coherent ice shelf grounding.

The southern Lomonosov Ridge off Greenland has a wide, flat, and $<1000 \mathrm{~m}$ deep area (Fig. 1). Although sea ice conditions impacted the quality of geophysical data collected there, the subbottom profiles reveal that the ridge crest shallower than $\sim 785 \mathrm{~m}$ water depth was subjected to extensive ice grounding (Figs. $2 \mathrm{~b}$ and 3 ). However, the quality of the multibeam data precludes a precise description of the glacial seafloor morphology. The shallowest part ( $\sim 940 \mathrm{~m}$ ) at the opposite end of the ridge, off the Siberian margin, contains no signs of glaciogenic seabed disturbance (Jokat, 1999). The central Lomonosov Ridge between about $85^{\circ}$ and $87^{\circ} 20^{\prime} \mathrm{N}$ is the area in the central Arctic Ocean where ice grounding was first mapped (Jakobsson, 1999; Jakobsson et al., 2008b; Polyak et al., 2001) (Fig. 1). Here grounded ice eroded the ridge crest down to $1000 \mathrm{~m}$ present water depth and scraped sediment off the crest. Eroded sediments were re-deposited on the leeward side of the grounded ice, indicating the direction of ice flow (Jakobsson et al., 2008b; Kristoffersen et al., 2004). Plowmarks from individual deep-keeled icebergs also occur in water depths shallower than $\sim 850 \mathrm{~m}$. Notably, there are two parts of the central Lomonosov Ridge shallower than $1000 \mathrm{~m}$ where the seabed is unaffected by thick glacier ice, the Oden Spur reaching $912 \mathrm{~m}$ and at $84^{\circ} 15^{\prime} \mathrm{N}$ where the ridge is $890 \mathrm{~m}$ deep (Jakobsson et al., 2008b). The observations of an undisturbed seabed in several areas shallower than $1000 \mathrm{~m}$ suggest that a coherent, $1000 \mathrm{~m}$ thick ice shelf did not exist in the central Arctic Ocean; however, we cannot exclude the possibility of a thinner ice shelf extending over these sites.

Based on previous side-scan images and subbottom profiles of the Yermak Plateau, the flat crest of the 510-530 m deep southern part of the plateau at about $80^{\circ} \mathrm{N} 8^{\circ} \mathrm{E}$ was attributed to grounding of an ice shelf forming a local ice rise (Vogt et al., 1994). Three alternative explanations were proposed for the Yermak Plateau ice grounding: that it was formed from (1) an extension of an ice dome centered on northern Svalbard, (2) from grounding of large tabular 

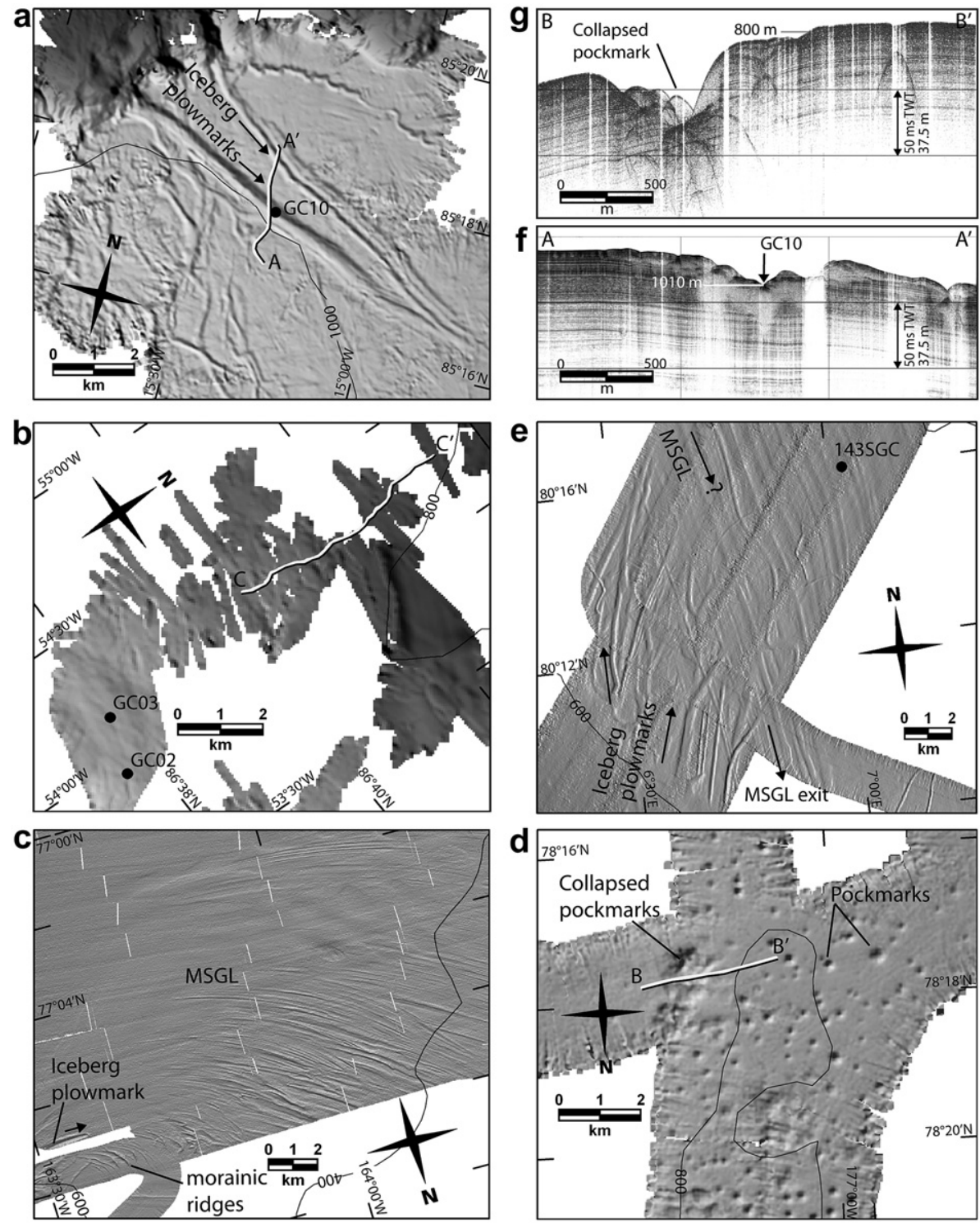

Fig. 2. Detailed multibeam maps showing swath bathymetric data from the Morris Jesup Rise (a), southern Lomonosov Ridge off Greenland (b), Chukchi Cap (c), Mendeleev Ridge (d) and Yermak Plateau (e). Studied sediment cores that are located within the detailed map areas are marked by black dots and the chirp sonar profiles $\mathrm{A}^{\prime}-\mathrm{A}$ and $\mathrm{B}-\mathrm{B}^{\prime}$ presented in (f) and (g) are shown by black/gray lines. The core locations are also shown in Fig. 1 along with that their full names are written in the figure caption. Chirp profile $\mathrm{C}-\mathrm{C}^{\prime}$ is shown in Fig. 3. Black arrows are inferred directions of iceberg scours.

icebergs originating elsewhere than northwestern Svalbard, or (3) from grounding of a continuous Arctic Ocean ice shelf (Vogt et al., 1994). Our new multibeam data cover an area further to the north on the plateau (Fig. 2e). Parallel glacial lineations are visible running in a north-northwest to south-southeast direction in this area. The lineations are on average about $520 \mathrm{~m}$ wide and have a relief of approximately $10 \mathrm{~m}$. Following Clark (1993), Dowdeswell et al. (2004) and Shipp et al. (1999), we henceforth refer to these large-scale glacial lineations as Mega Scale Glacial Lineations (MSGL). However, it should be noted that the MSGL mapped, for example in Antarctica and along the Norwegian continental margin, are generally confined to bathymetric troughs and interpreted to indicate fast flowing ice streams. The features mapped in this work are similar in morphology, but instead of occurring in a bathymetric trough they are confined to shallow bathymetric highs. The MSGL mapped on the Yermak Plateau extend to a water depth of $\sim 600 \mathrm{~m}$ and suggest the presence of coherent ice grounding on the plateau. Furthermore, the MSGL appear to exit along the southwestern part of the study area, which might indicate that large tabular icebergs, calved from a thick ice shelf or ice sheet outlet glacier, grounded on the Yermak Plateau on their way from the Arctic Ocean to the Fram Strait. This is consistent with the second explanation suggested by Vogt et al. (1994). However, our multibeam swath bathymetry does not cover the most southerly edge of the Yermak Plateau and we cannot rule out that the MSGL were instead formed from an ice sheet extending from Svalbard. This would imply a rather unusual ice sheet configuration as the ice sheet would need to thicken beyond the generally less than $200 \mathrm{~m}$ deep continental shelf of northern Svalbard (Fig. 4). Basal freezing in this area also seems unlikely considering the proximal location to the North Atlantic. The multibeam data also show systematic sets of plowmarks from deep drafted icebergs entering the plateau from both the southwest and northeast. These scours were likely caused by icebergs produced by ice streams of the Eurasian Ice Sheet; a topic further developed by Dowdeswell et al. (submitted for publication).

The Chukchi Borderland is comprised of a group of generally less than $1000 \mathrm{~m}$ deep parallel north-trending ridges north of the 


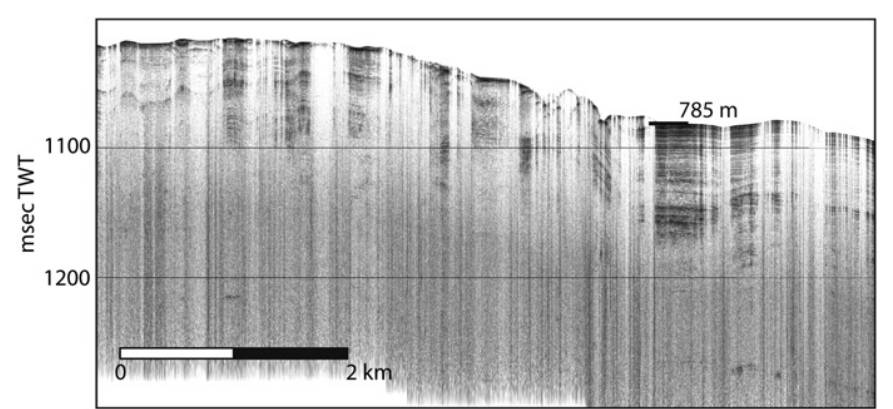

Fig. 3. Chirp sonar profile from the southern Lomonosov Ridge. Glacial erosion starts from about $785 \mathrm{~m}$ present water depth along this particular profile. The data was acquired during the LOMROG 2007 expedition in 10/10 and $+4 \mathrm{~m}$ thick sea ice. The location of the profile is marked in Fig. 2.c

Chukchi shelf. These ridges provide abundant evidence of glacial influence including flutes and MSGL, drumlins, morainic ridges, and iceberg plowmarks (Jakobsson et al., 2005; Jakobsson et al., 2008b; Polyak et al., 2007; Polyak et al., 2001). The new data acquired from USCGC Healy in 2009 reveal MSGL on the eastern part of the Chukchi Cap in water depths shallower than $450 \mathrm{~m}$ (Fig. 2c). These are $\sim 4-20 \mathrm{~m}$ in relief and with crest-to-crest distances ranging from $\sim 100$ to $>300 \mathrm{~m}$ (Fig. 2c). Their characteristics are similar to MSGL mapped on the continental shelf surrounding Antarctica (Heroy and Anderson, 2005). Different sets of lineations cross cut one another suggesting multiple events with slightly different ice flow directions (Fig. 2c). However, it is not possible to conclude from the mapped glacial morphology whether the ice flowed from the northwest or southeast. In the northeastern corner of the mapped area, formations that appear to be morainic ridges are located near the edge of the ridge crest (Fig. 2c). These are on the order of $10 \mathrm{~m}$ high and have curvelinear shapes. Similar to the Morris Jesup Rise, occasional icebergs plowed into the eastern edge of the Chukchi Cap leaving deep plowmarks (Fig. 2c). Orientations of glaciogenic features found on the Alaska-Beaufort Margin (Engels et al., 2007), suggest that ice masses may first have extended from the northwestern margin of the Laurentide Ice Sheet to the Chukchi Borderland forming the nucleus of a local ice rise, which eventually may have developed into its own ice sheet.

Near $78^{\circ} \mathrm{N}$, the Mendeleev Ridge has a minimum depth of $772 \mathrm{~m}$ (Fig. 1). Irregularities in the seafloor are apparent on subbottom profiles, but multibeam data clearly show that these are not typical features formed by glacial ice but rather that the seafloor is dominated by pockmarks (Fig. 2d). The absence of glacial features on this $772 \mathrm{~m}$ deep portion of the Mendeleev Ridge is a strong indication that the region remained free from the influence of a $1000 \mathrm{~m}$ thick floating ice shelf. However, the southernmost part of the Mendeleev Ridge between $76-77^{\circ} \mathrm{N}$ (known also as the Arlis Plateau) was recently reported to be heavily eroded at water depths between about 800 and $900 \mathrm{~m}$ and retrieved sediment cores reveal that the erosional surface lies beneath a diamicton tentatively dated to MIS 5.2 or 5.3 or older (Stein et al., in press).

\subsection{X-ray identification of ice erosional surfaces}

X-radiographs of core LOMROG07-GC-10, retrieved from the bottom of an iceberg plowmark on the Morris Jesup Rise (Fig. 2a), reveal a clear angular erosional surface between 127 and $129 \mathrm{~cm}$ (Fig. 5). Below this boundary sediments are fine grained and show

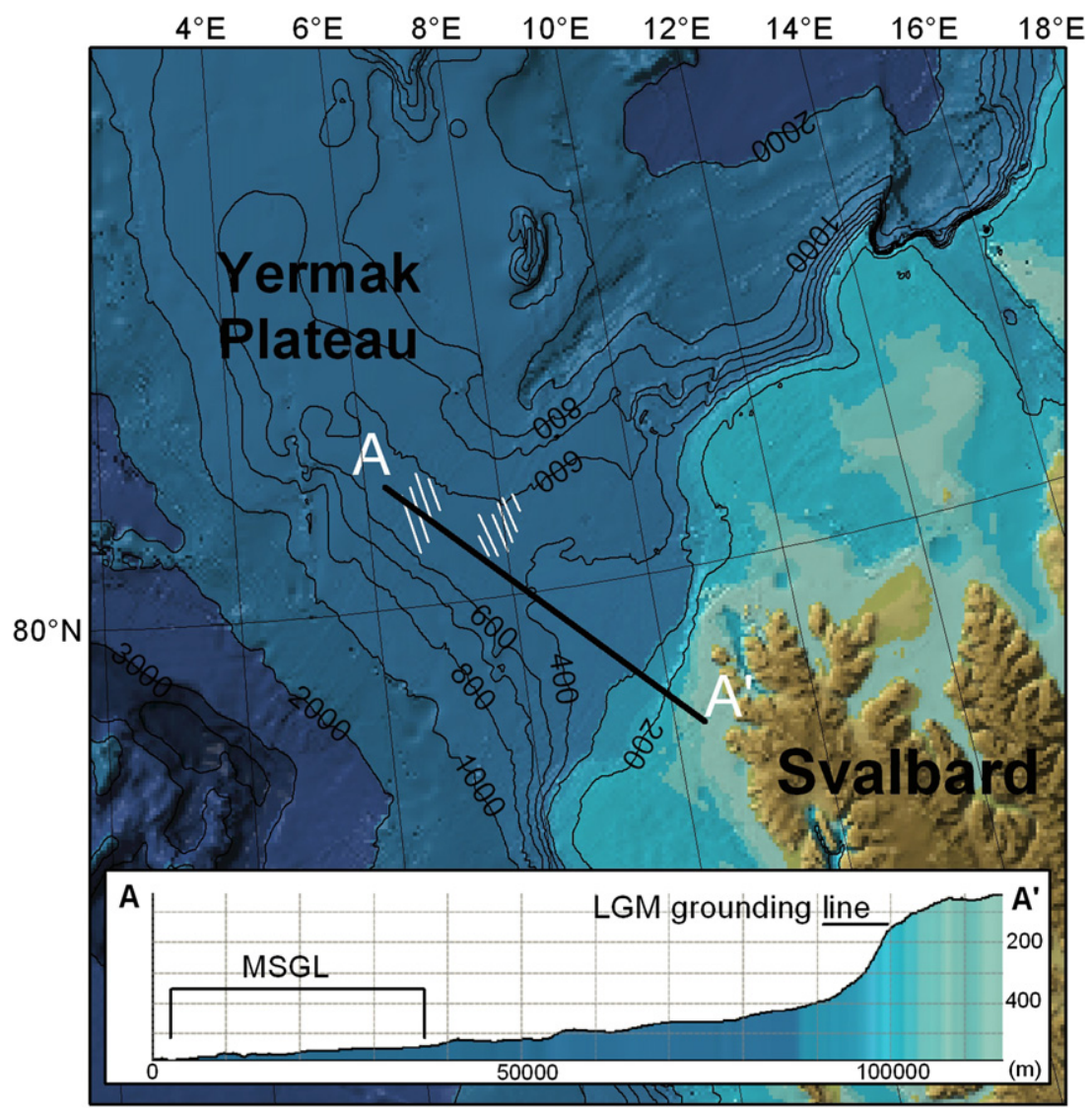

Fig. 4. Profile from the northern Svalbard continental margin to the MSGL mapped on the southern Yermak Plateau. If the MSGL were formed from an ice sheet extending from Svalbard it would need to thicken beyond the generally less than $200 \mathrm{~m}$ deep shelf as the MSGL are located in water depths down to $600 \mathrm{~m}$. 

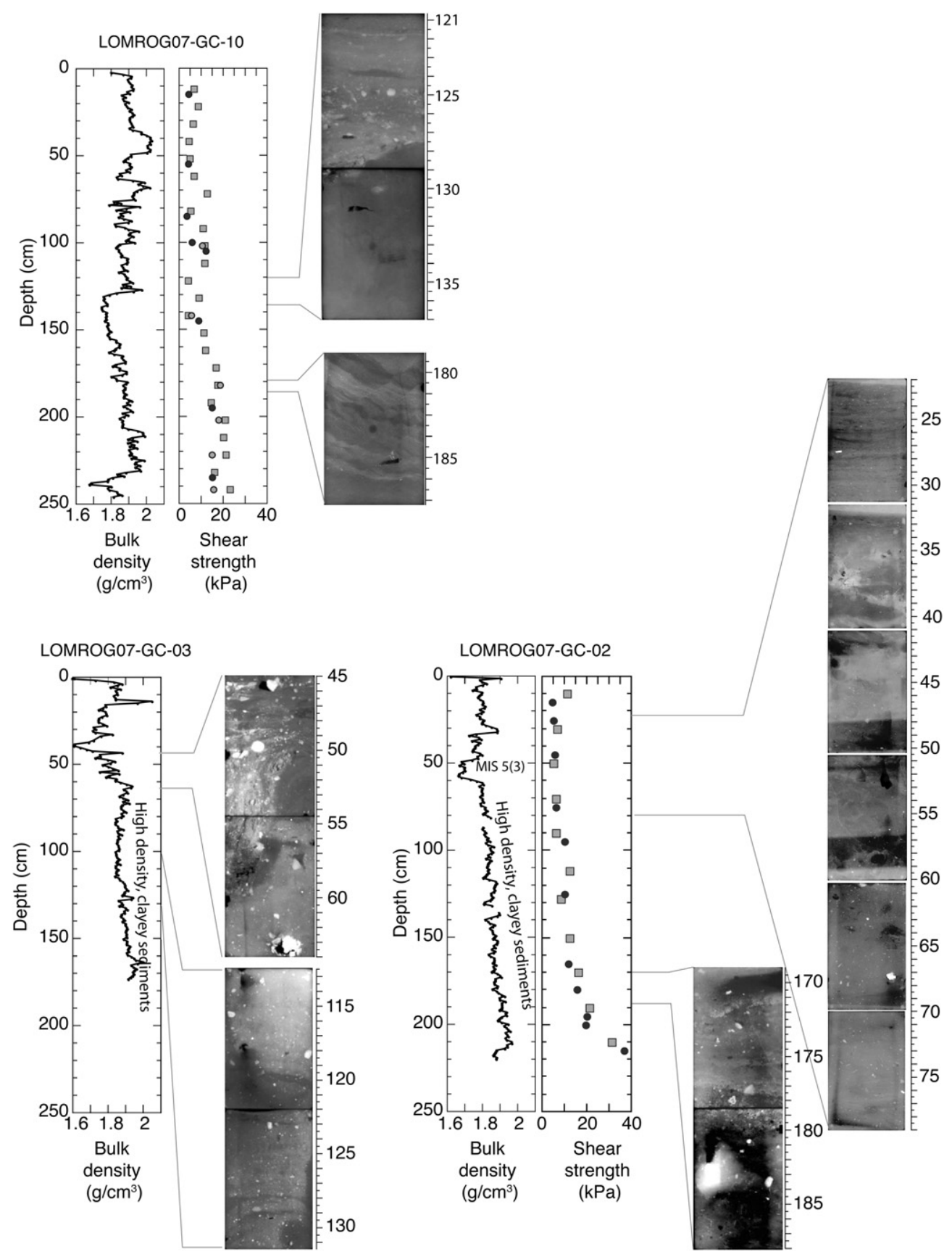

Fig. 5. Bulk density, shear strength and X-Ray images of core LOMROG07-GC10 from the Morris Jessup Rise and LOMROG07-GC02, 03 from the southern Lomonosov Ridge off Greenland. Shear strength data collected using a pocket penetrometer (squares) or hand held Torvane (circles).

signs of deformation. In contrast, directly above this boundary the sediments are enriched in ice rafted debris (IRD). Shear strength and bulk density show notable changes at the level where X-ray images reveal the erosional surface. The decrease in sediment density below the erosional surface, corresponding to an increase in sediment porosity, is not consistent with overconsolidated sediments, and may be an artifact of subglacial deformation or the infilling of the plowmark by slope failure. In cores LOMROG07-GC02 and LOMROG07-GC-03 from the southern Lomonosov Ridge sharp boundaries indicating erosional surfaces are also observed. It is not possible to irrefutably attribute these surfaces to iceberg/ice sheet grounding. However, both cores show a shift towards higher and less variable bulk density below approximately $60 \mathrm{~cm}$ (Fig. 5).
In core LOMROG07-GC-02, the increase in bulk density and moderately elevated shear strength occur below the nannofossil bearing unit. The sediment physical properties below $60 \mathrm{~cm}$ are thus consistent with low porosity glacially deformed sediments.

\subsection{Dating of Arctic Ocean glaciogenic bedforms}

The age of the ice grounding event mapped on the central Lomonosov Ridge was obtained by dating the stratigraphic unit resting directly above the ice-eroded surface (Jakobsson et al., 2001) (Fig. 6a). The onset of sedimentation after the ice grounding was during MIS 5.5, implying that the grounding event occurred during MIS 6. Cores from areas of ice grounding on the 

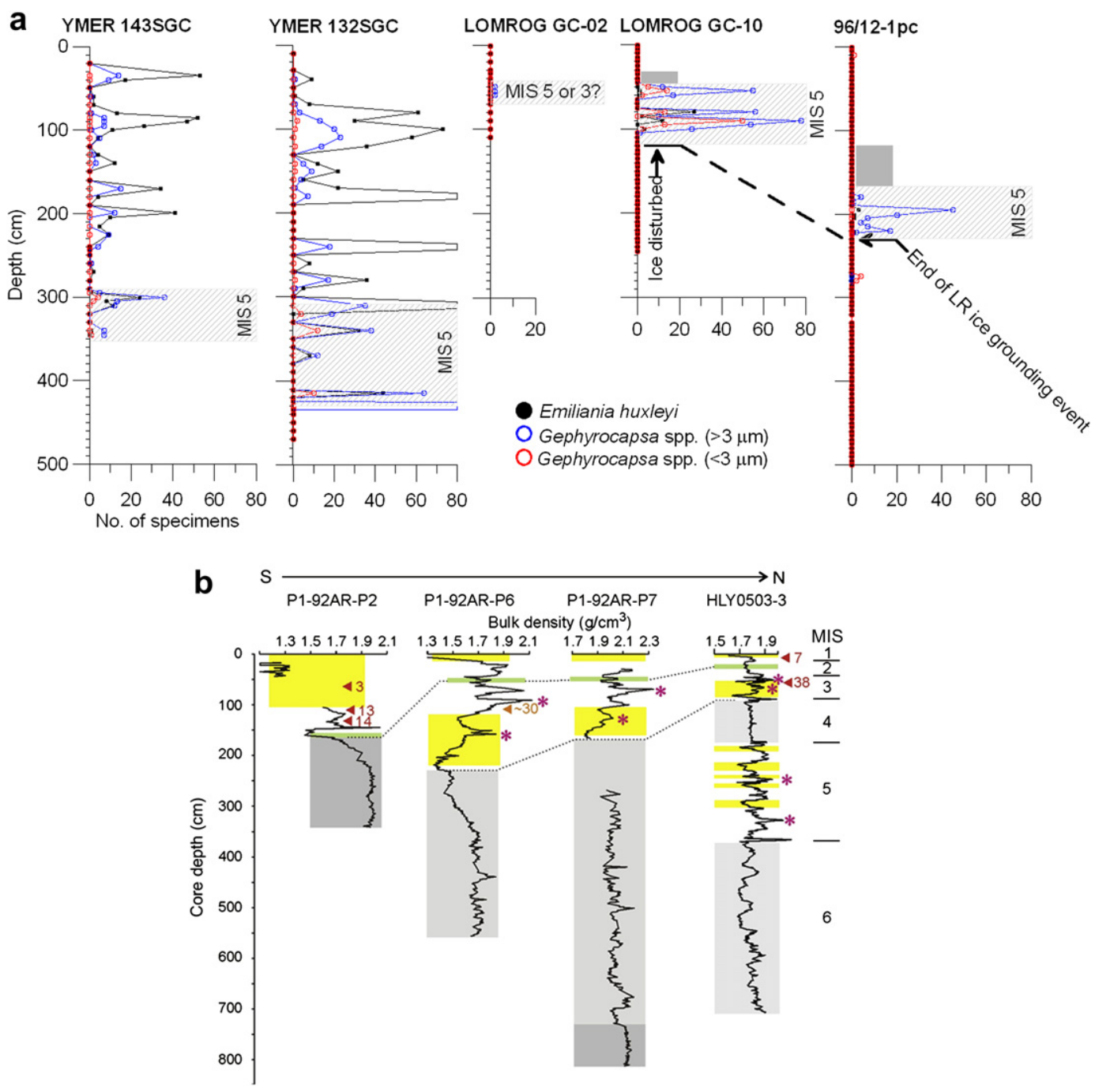

Fig. 6. Sediment cores from the Eurasian Basin (a) and the Amerasian Basin (b) discussed and studied in this work. Core locations are shown in Figs. 1 and 2. (a) Calcareous nannofossil abundance of the three main taxonomic categories (Emiliania huxleyi, medium-sized ( $>3 \mu \mathrm{m})$ and small ( $<3 \mu \mathrm{m})$ Gephyrocapsa spp.) in Ymer cores 132SGC and 143SGC as well as in LOMROG cores GC-02 and GC-10 all retrieved from ice eroded areas (see Fig. 1 for core locations). From these biostratigraphic results the location of MIS 5 is inferred in all cores. Reference core 96/12-1pc from the central Lomonosov Ridge (Jakobsson et al., 2001) is included for correlation purposes. (b) Correlation of cores containing glacial sediments along the Northwind Ridge. New data are presented for core HLY0503-3JPC while the data from the other cores were published by Polyak et al. (2007). Lithology: dark gray, subglacial diamicton; light gray, glacially-displaced sediment; yellow, interglacial-type sediment units; green, LGM fine-grained sediment with distinct IRD composition (Polyak et al., 2009). Numbers to the right of the cores show ${ }^{14} \mathrm{C}$ or amino-acid racemization ages; asterisks show prominent peaks of detrital carbonates. Inferred Marine Isotopic Stages (MIS) are shown on the right.

southwestern Lomonosov Ridge, the Yermak Plateau and from one of the deep iceberg scours on the Morris Jesup Rise were investigated with respect to calcareous nannofossils (Figs. 1, 2 and 6a). The biostratigraphy is based on abundance relationships of three main taxonomic categories, Emiliania huxleyi, and medium-sized $(>3 \mu \mathrm{m})$ and small $(<3 \mu \mathrm{m})$ Gephyrocapsa spp. (Backman et al., 2009), and through correlation to a reference core from the Lomonosov Ridge where MIS 5 is established (Jakobsson et al., 2000). Correlation of MIS 5 is straightforward from the reference core to core GC-10 (Fig. 6a) from the Morris Jesup Rise, as well as to other cores in the Eurasian Basin, with presence of $E$. huxleyi and dominant medium sized gephyrocapsids below a gray sediment layer. These data show that the large iceberg scours on the Morris Jesup Rise were formed during MIS 6.

In Core GC-02 from the Lomonosov Ridge off Greenland, only rare nannofossils were observed in three samples. These few specimens were all medium sized gephyrocapsids (Gephyrocapsa muellerae, Gephyrocapsa caribbeanica), which are interpreted to represent MIS
5, or possibly MIS 3, because MIS 7 would likely be represented by small gephyrocapsids and MIS 1 by E. huxleyi. Thus, the existence of MIS (3)5 sediments on top of a heavily eroded surface suggests a PreMIS (3)5 age for the ice grounding, most likely MIS 6.

The two Yermak Plateau cores, Ymer 132SGC and 143SGC, correlate well to other dated reference cores (V27-60, PS2008-2) (Dowdeswell et al., submitted for publication). The nannofossil stratigraphy of core 143SGC indicates that MIS 5.1 occurs at $300-305 \mathrm{~cm}$, and MIS 5 is still present in the lowermost nannofossil bearing sample at $345 \mathrm{~cm}$ at the base of the core. Furthermore, integration with chirp sonar profiles reveals that core 143SGC did not fully penetrate the sediment drape on top of the MSGL. This is further addressed below.

The lower part of core 132SGC has an unusually nannofossil rich sample at $430 \mathrm{~cm}$ interpreted to represent MIS 5.5. MIS 5.1 is tentatively placed in the $310-340 \mathrm{~cm}$ interval, and late MIS 3 is tentatively placed at ca $120 \mathrm{~cm}$. These findings are consistent with an integrated stratigraphy for the Yermak Plateau illustrating that 

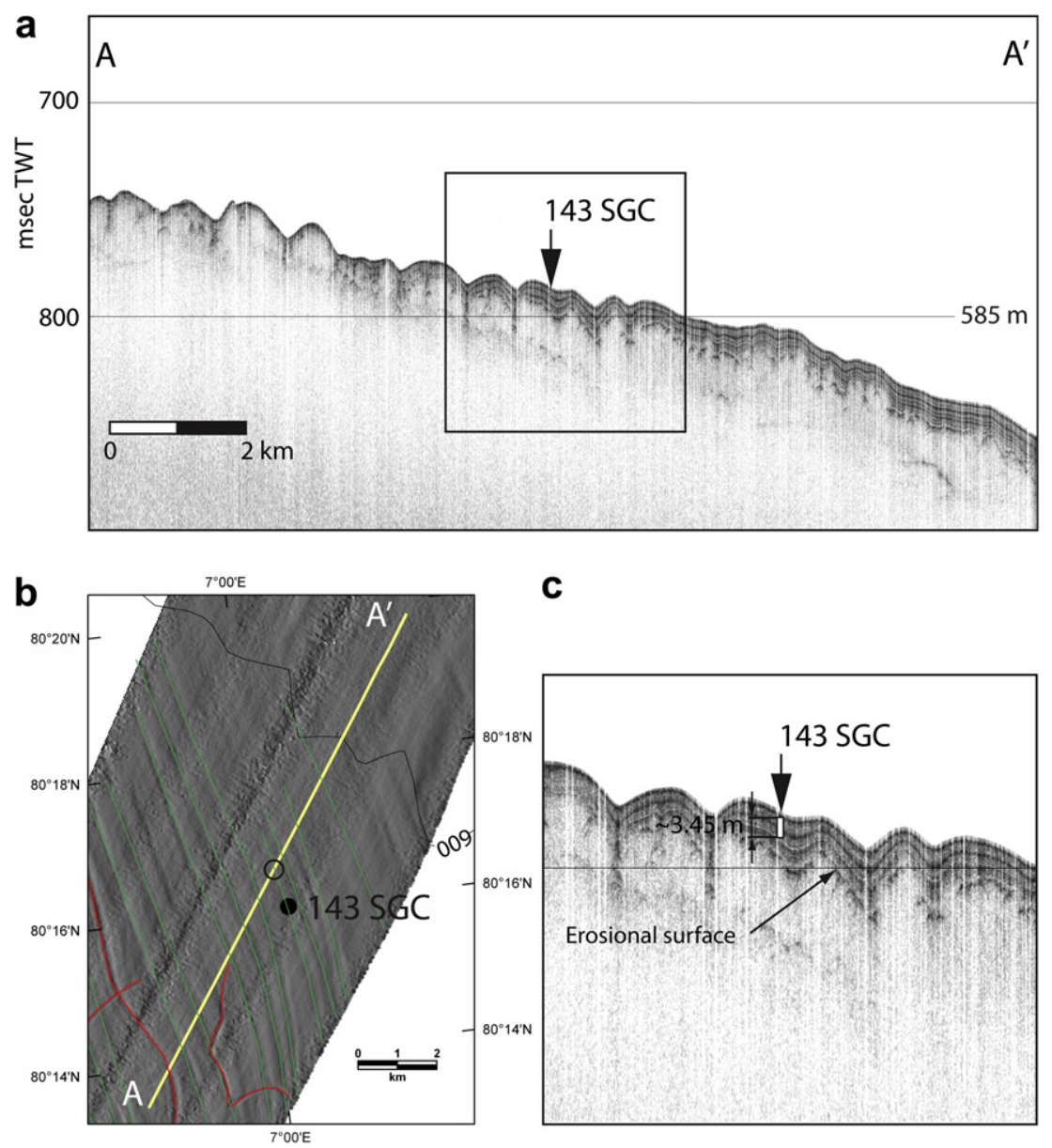

Fig. 7. (a) Chirp sonar profile across the southern part of the Yermak Plateau. The location of the profile is shown in (b). The black box indicates the enlarged part of the chirp sonar record shown in (c). (b) Shaded relief produced from the multibeam bathymetry acquired in the area of Ymer core 143SGC during the LOMROG 2007 expedition. Glacial lineations are indicated by green lines and some identified iceberg scours, post-dating the glacial lineations, are marked by red lines. The 143SGC coring site was projected onto the chirp sonar profile along a glacial lineation. The resulting position from this exercise is marked by a circle. (c) The projected location of site 143SGC shown on the chirp sonar profile. The penetration depth of the core is marked by a white bar (see text for details on the conversion from core depth to two-way travel time).

a continuous drape of sediments exists from at least MIS 5 time, and that the likely formation of the glacial lineations was during MIS 6 (Dowdeswell et al., submitted for publication).

The nature and timing of the Chukchi Borderland glacial history seems particularly complex since the degree and type of glacial erosion varies in depth, and glaciogenic bedforms are superimposed on each other at some sites (Jakobsson et al., 2008b) (Fig. 2c). Core stratigraphies from the southern end of the Northwind Ridge include two glacial erosional events, the first during the LGM and the second, more extensive erosion at an earlier time, but clearly younger than MIS 6, most likely MIS 4 (Polyak et al., 2007). HOTRAX core HLY0503-3JPC from the northern end of the Northwind Ridge immediately down-slope from the eroded area contains two intervals of non-stratified, diamict-type sediment embedded in the normal stratigraphic sequence (Fig. 6b). These intervals were presumably formed by sediment displaced by eroding ice from the ridge top during ice-grounding events. The correlation of this core with earlier investigated Northwind Ridge stratigraphies indicates that the upper diamicton corresponds to the widespread MIS 4 erosion at the more southern sites, whereas the lower diamicton is older. Although the exact age of the sub-MIS 4 sediments is yet to be determined, the stratigraphy between the two diamict intervals is very similar to MIS 5 investigated on the Mendeleev Ridge (Adler et al., 2009), which suggests the most likely age of the lower diamicton is MIS 6 (Fig. 6b).
It must be noted that the Mendeleev Ridge core HLY0503-8JPC has a slump unit emplaced in late MIS 6, which may also be indirect evidence for the erosion of the ridge top during this time (Adler et al., 2009). There is no core available from the area with the well preserved glacial lineations on the Chukchi Cap shown in Fig. 2c.

\subsection{Core-seismic integration on the Yermak Plateau}

The chirp sonar records from the southern Yermak Plateau, where the seafloor is dominated by prominent parallel glacial lineations from about 575 to $560 \mathrm{~m}$ water depth, reveal no subbottom penetration of the acoustic signal, suggesting either a hard seafloor or some degree of sediment reworking. Deeper than approximately $575 \mathrm{~m}$, a drape of acoustically stratified sediments is imaged on top of the glacial lineations (Fig. 7). This relatively thin (5-6 m) drape of sediment can be seen above $575 \mathrm{~m}$ water depth in some of the "troughs" between the elevated portions of the lineations. Core 143SGC is not located directly on any of the chirp sonar profiles acquired during LOMROG 2007. In order to find the most representative part of the acoustic stratigraphy for core 143SGC, the glacial lineations are used as a guide to project the coring site onto the nearest chirp sonar profile (Fig. 7). The projected distance from the coring site to the nearest chirp sonar profile along a glacial lineation is approximately $1000 \mathrm{~m}$. Eq. (1) is derived from measurements of physical properties from Ocean Drilling Program 


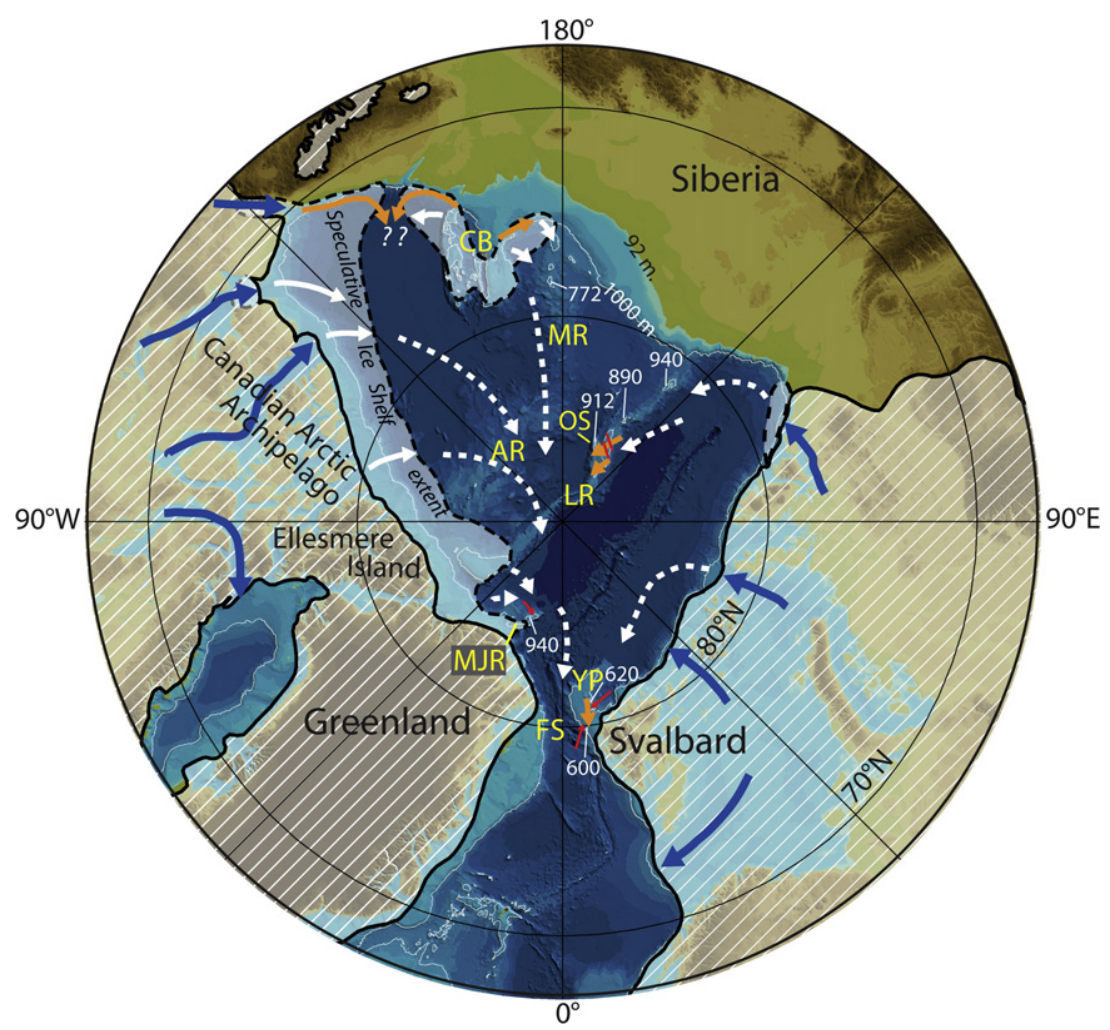

Fig. 8. Tentative reconstruction of MIS 6 ice shelves. Orange arrows indicate ice flow inferred from geophysical mapping and white arrows hypothesized ice flow. Red arrows show scours from deep-keeled icebergs while red lines show iceberg scours where the direction is not possible to conclude. The portrayed bathymetry is derived by lowering the recently estimated sea level drop during MIS 6 of $92 \mathrm{~m}$ (Rabineau et al., 2006) from the International Bathymetric Chart of the Arctic Ocean (IBCAO) (Jakobsson et al., 2008a). Areas shallower than $1000 \mathrm{~m}$ present water depth where geophysical mapping shows no glacial erosion are pointed to by thin white lines; the numbers represent the shallowest water depth in each area, i.e. in order to derive the MIS 6 water $92 \mathrm{~m}$ must be subtracted. The Eurasian Late Saalian Ice Sheet (MIS 6) is inferred from the reconstruction by the Quaternary Environment of the Eurasian North (QUEEN) project (Svendsen et al., 2004). The North American Ice Sheet shown is the Late Wisconsinan by Dyke et al. (2002), updated to include Banks and Melville Islands as ice covered (England et al., 2009), assuming that the late Illinoian Ice Sheet (MIS 6) covered at least this area in the Arctic region. See the caption of Fig. 2 for the abbreviations of feature names.

Leg 151, Site 910 (Shipoard Scientific Party, 1995) on the Yermak Plateau and allows conversion of acoustic Two-Way Travel time (TWT) in seconds to depth below seafloor:

$z=0.846(\mathrm{TWT})+0.000114(\mathrm{TWT})^{2}$

Core 143 SGC is $3.45 \mathrm{~m}$ long and, applying Eq. (1), this corresponds to $\sim 4.1 \mathrm{~ms}$ TWT. Inserting this estimated penetration of core 143SGC into the chirp sonar profile at the projected location shows that the core likely did not fully penetrate through the drape and across the ice grounding surface (Fig. 7c). The nannofossil stratigraphy indicates that MIS 5 is still present at the bottom of core 143SGC. Therefore, we suggest that the ice grounding responsible for the glacial lineations on the Yermak Plateau and the erosional surface marked in Fig. 7c occurred prior to MIS 5, i.e. MIS 6. The Yermak Plateau regional stratigraphy is further developed in Dowdeswell et al. (submitted for publication) and O'Regan et al. (submitted for publication).

\section{Discussion}

\subsection{An Arctic Ocean Ice Shelf in the Amerasian Basin}

The present collection of geophysical data from the Arctic Ocean does not support the existence of a continuous $1000 \mathrm{~m}$ thick Arctic ice shelf because numerous bathymetric highs that would have been affected by such an ice shelf show no evidence of glacial overriding (Fig. 8). Previous studies of the Chukchi Borderland suggest the re-current influence of ice grounding attributed to ice shelves extending from the northern margin of the Laurentide Ice Sheet combined with an ice rise formed over the borderland (Jakobsson et al., 2008b). This is corroborated by traces of ice shelf grounding along the Alaska-Beaufort margin (Engels et al., 2007). Furthermore, the flat topped nature of the southern Lomonosov Ridge north of Greenland and the data presented here indicate extensive ice grounding and the possible formation of local ice rises in this area. The Morris Jesup Rise has the deepest iceberg plowmarks mapped in the Arctic Ocean, and the Yermak Plateau has the imprints from huge tabular icebergs that grounded as they drifted towards the Fram Strait.

Taken together, the geophysical and geological data from the Arctic Ocean suggest that the largest Quaternary marine ice sheet complex, including thick ice shelves, existed during MIS 6. It is important to stress that it is not possible to determine precisely the extent of such an Arctic Ocean ice shelf since a floating ice shelf per se does not leave any direct geomorphic traces on the seafloor. Iceberg plowmarks and MSGL formed from ice shelves grounding on, and passing over, shallow bathymetric highs such as the Yermak Plateau are only indirect evidences of the existence of thick ice shelves and do not reveal their precise spatial extents. However, from the geographical spread of the geophysical and geological datasets, ice shelves appear to have been primarily restricted to the Amerasian part of the Arctic Ocean. Assuming that the southern part of the Lomonosov Ridge off Greenland and Chukchi Borderland both hosted ice rises and the large glacial troughs of the Canadian Arctic Archipelago fed the MIS 6 ice shelf, its extent is roughly inferred in 
Fig. 8. In this figure, the areas of ice sheet grounding are inferred to reach to the shelf break around much of the margin of the Arctic Basin. The speculative extent of the ice shelf into deeper water is indicated in Fig. 8. This extent of the ice shelf was estimated using a thinning rate of $5 \mathrm{~m}$ per $\mathrm{km}$ beyond the grounding line (Martin Siegerts, pers. comm.). The general maximum seaward limit is defined where the ice shelf thins to a thickness of $200 \mathrm{~m}$. The only exception is the Beaufort Sea area, where there are signs of ice shelf grounding along the continental margin (Engels et al., 2007).

In this context the traces of ice grounding on the central Lomonosov Ridge remain the most enigmatic of the described features, as their direction suggests a Eurasian source for the eroding ice. Previous interpretations of the MIS 6 erosional event on the central Lomonosov Ridge include grounding of deep-drafted icebergs tightly clustered in armadas (Kristoffersen et al., 2004) or grounding of an ice shelf extending from the BarentsKara Sea Ice Sheet (Jakobsson et al., 2008b). Another possible explanation is grounding of a large fragment of an ice shelf that existed somewhere along the Barents-Kara Ice Sheet, presumably located in the innermost part of the Nansen Basin out of reach of warm Atlantic water (Fig. 8). The two eroded areas on the central Lomonosov Ridge total $\sim 5700 \mathrm{~km}^{2}$, implying that the grounded ice shelf fragment (giant iceberg) would have to be in this size in order to generate the spatially coherent ice grounding marks mapped on the ridge crest. The largest icebergs presently calved from Antarctic ice shelves reach this size and may occasionally be much larger, as exemplified by the $>11,000 \mathrm{~km}^{2}$ B15 iceberg that broke off the Ross Ice Shelf in 2000 (Joughin and MacAyeal, 2005).

\subsection{The role of the Atlantic water influx and the Arctic Ocean cold halocline}

By postulating that the growth of Antarctic-sized ice shelves in the Arctic Ocean is prevented by the inflow of warm Atlantic waters, it becomes important to address what oceanographic mechanisms and processes would inhibit Atlantic water from reaching the Amerasian Basin and, thus, allow ice shelf formation? One possibility is that Polar Surface Water, forming a cold halocline, extended to deeper water depths and consequently forced the Atlantic water deeper. The depth of the cold halocline is primarily controlled by the freshwater input from rivers and by windinduced vertical mixing acting to force the buoyant freshwater downward (Stigebrandt, 1981). Perhaps counter-intuitively, a weaker freshwater input results in a deeper halocline (Nilsson and Wallin, 2010; Stigebrandt, 1981). The MIS 6 Arctic Ocean likely received substantially less freshwater because the hydrological cycle is generally weaker in colder climates (Held and Soden, 2006) and specifically the rivers ending in the Barents and Kara Seas were blocked by a very large Eurasian Ice Sheet (Svendsen et al., 2004). Furthermore, $\sim 0.8 \mathrm{~Sv}$ of fresher water (32.5 psu) is presently entering through the Bering Strait (Woodgate and Aagaard, 2005) which, with a threshold of approximately $52 \mathrm{~m}$, was closed during the peak of MIS 6 (Rabineau et al., 2006). Provided that the wind-induced vertical mixing was comparable to that in the present climate, the cold halocline would deepen from 130 to $510 \mathrm{~m}$ if the freshwater supply was reduced from today's $0.28 \mathrm{~Sv}$ to 0.1 (Appendix 1).

Another way to restrict the inflow of Atlantic water is to change the ocean surface stress acting in the Nordic Seas and the Arctic Ocean along the closed depth contours. This can be accomplished by altered surface wind stress, but also by the presence of thick perennial sea ice. Atmospheric modeling studies indicate more prevailing anticyclonic wind conditions over the MIS 6 Arctic Ocean with the limited ice shelf in the Amerasian Arctic as proposed in this study (Colleoni et al., submitted for publication). This would reduce the net cyclonic surface stress along the closed depth contours and thereby act as a barrier to Atlantic water circulation; the wind-forced Atlantic water circulation in the Arctic could even cease if the integrated surface stress completely changed sign to become anticyclonic (Nøst et al., 2008).

Finally, if the MIS 6 Arctic Ocean was more weakly stratified due to less freshwater influx, then an even greater fraction of the Atlantic water would be forced to follow the depth contours than at present. At critical narrow passages in the bottom morphology, such as where the Lomonosov Ridge meets the Siberian continental margin, modest changes in density may yield reorganizations of the basin-scale circulation pattern, with the Lomonosov Ridge acting as a topographic barrier to exchange with the Amerasian Basin. Therefore, weaker Arctic Ocean density stratification together with an ice sheet covering the Barents Sea in the Saalian period could result in Atlantic water being restricted to the Eurasian Basin. This conceptual model, in which Atlantic water inflow persists, perhaps episodically, during glacial periods but is restricted to the Eurasian Basin is in agreement with evidence for Atlantic water inflow to the Norwegian-Greenland Sea and through the Fram Strait reported at 145, 165 and 180 ka (Hebbeln and Wefer, 1997; Lloyd et al., 1996). Furthermore, interpretations based on the occurrence of warm-water dinoflagellate cysts, benthic foraminifera and the abundance of biogenic calcite, indicate penetration of warm Atlantic waters to the northern Barents Sea margin, at least to the Franz Victoria Trough, during the later part of MIS 6, MIS 3 and MIS 2 (Knies et al., 2000; Knies and Stein, 1999; Matthiessen and Knies, 2001). There is no indication of Atlantic water influence during MIS 6 in cores from the shelf off Severnaya Zemlya, with warmer water suggested only during the Holocene and Stage 5.5 (Knies et al., 2001).

\subsection{An Arctic Ocean ice shelf during MIS 6 versus MIS 2}

Ice shelves have likely existed in the Arctic Ocean during several Quaternary glaciations. For example, a 635+ m thick ice stream in the M'Clure Strait that fed an ice shelf beyond its grounding line is suggested in a recent reconstruction of the Late Wisconsinan Laurentide Ice Sheet (England et al., 2009). Our data do not support a continuous $1000 \mathrm{~m}$ thick Arctic Ocean ice shelf during the LGM, as previously suggested (Grosswald, 1988; Grosswald and Hughes, 2008; Hughes et al., 1977), principally because there is little evidence to suggest ice-grounding on the Morris Jessup Rise, Lomonosov Ridge or Yermak Plateau during the LGM. All the geophysical and core data indicate notable grounding events prior to the LGM. This is further corroborated by continuous ice-rafting from the Laurentide and Innuitian Ice Sheets found in Arctic Ocean cores during the entire MIS 2 (Darby and Zimmerman, 2008). Cores from Fram Strait and the central Arctic show detrital Fe grains chemically matched to these ice sheets with large abundance peaks in these grains every few thousand years indicating large numbers of icebergs exiting Fram Strait during MIS 2.

The Eurasian Ice Sheet during the Late Saalian period (160-140 ka) was substantially larger than the Weichselian ice sheets (MIS 5 to MIS 2) (Svendsen et al., 2004). However, it is not obvious why the most extensive ice shelves and deepest keeled icebergs existed during MIS 6, or why Atlantic water inflow would be more restricted during this glacial period. Astronomical forcing was suggested as an explanation for this observation (Colleoni, 2009). The eccentricity of the Earth's orbit was much larger between 160 and $140 \mathrm{ka}$ than during the LGM. This enhanced the precession cycle and influenced the amount of solar downward radiation at the top of the atmosphere. Between approximately 160 and $144 \mathrm{ka}$ insolation during summer and fall was higher compared 
to LGM, which, according to Atmospheric General Circulation simulations, had a positive effect on the Eurasian Ice Sheet's surface mass balance. However, during the MIS 6 glacial maximum at about $140 \mathrm{ka}$ the solar downward radiation at the top of the atmosphere was $\sim 20 \mathrm{~W} / \mathrm{m}^{2}$ lower during spring and summer than during the LGM. Cooler spring and summer temperatures in the Arctic would likely result in less precipitation further reducing the freshwater influx to the Arctic and subsequently deepening the halocline and, thus, providing favorable conditions for ice shelf development.

\section{Conclusions}

Geophysical mapping of the southern Lomonosov Ridge off Greenland, Morris Jesup Rise, Chukchi Borderland and Yermak Plateau in the central Arctic Ocean portray MSGL and iceberg plowmarks that constrain the existence of thick ice shelves and deep drafting icebergs during previous glacial periods. The deepest iceberg plowmarks are mapped on the Morris Jesup Rise and extend to $1045 \mathrm{~m}$ below present sea level. Dating of sediment cores from the ice grounded areas suggest that the deepest iceberg plowing on the Morris Jesup Rise, central and southern Lomonosov Ridge as well as the formation of MSGL on the Chukchi Borderland and Yermak Plateau took place during MIS 6. Several areas in the central Arctic Ocean shallower than $1000 \mathrm{~m}$ below present sea level are, however, unaffected by ice erosion suggesting that the hypothesis of a continuous $1000 \mathrm{~m}$ thick ice shelf in the central Arctic Ocean can be rejected. From the mapped evidence of iceberg plowing and ice shelf grounding, as well as the mapped un-eroded bathymetric highs, we tentatively outline the extent of a MIS 6 Arctic Ocean ice shelf. We propose that influx of Atlantic water restricted ice shelf formation in the Eurasian Arctic Ocean, although the existence of deep bathymetric troughs, such as the St Anna Trough, bear witness to large ice streams that could have provided sufficient ice flux for the development of ice shelves at some points during the Quaternary.

\section{Acknowledgements}

The LOMROG 2007 expedition was carried out by the Swedish Polar Research Secretariat (SPRS) and the HOTRAX expedition as a collaboration between SPRS and the US National Science Foundation (NSF). We thank the Captains and Crews on the Oden and Healy icebreakers. Financial support was received from the Swedish Research Council (VR), the Swedish Royal Academy of Sciences through a grant financed by the Knut and Alice Wallenberg Foundation and the Bert Bolin Centre for Climate Research at Stockholm University through a grant from FORMAS. The Knut and Alice Wallenberg Foundation, VR and Swedish Maritime Administration financed the multibeam installation on the icebreaker Oden. We thank John Anderson and an anonymous reviewer for their helpful comments on the manuscript.

\section{Appendix 1. A conceptual model of the Arctic Ocean cold halocline}

The stratification of the Arctic Ocean has three distinct layers (Rudels, 1995): The cold halocline comprised of near-freezing point low salinity water, the intermediate Atlantic layer of warmer and more saline water, and the cold deep-water layer. The physics controlling the cold halocline can be examined with an analytical two-layer model (Nilsson and Wallin, 2010; Stigebrandt, 1981) consisting of an upper-layer halocline situated above and interacting with a layer of Atlantic water. The equatorward volume transport in the cold halocline, exported to the Atlantic, is denoted $M$ and is much larger than the freshwater input $F$ to the upper layer in the Arctic Ocean. As a result, conservation of salinity in the halocline layer is given by

$\Delta S M=S_{0} F$

where $\Delta S$ is the salinity difference between the Atlantic water and the halocline water and $S_{0}=35$ is a constant reference salinity. The volume of the upper halocline layer, given by its surface area $(A)$ multiplied by its depth $(H)$, is in a steady state determined by a balance between the equatorward volume export and the windinduced mixing that acts to deepen the upper layer by incorporating Atlantic water. The export of water is assumed to be geostropically controlled (Stigebrandt, 1981), whereas the upwelling of the Atlantic water into the halocline layer is taken to be proportional to the energy input from the wind to turbulent mixing (denoted $\epsilon$ per unit area) and inversely proportional to the halocline depth and the density difference between the halocline and the Atlantic layer $(\Delta \rho)$ (Kato and Phillips, 1969). Solving for the steady-state upper-layer depth and the volume export, one obtains (Nilsson and Wallin, 2010)

$H=\left(\frac{A \varepsilon 2 \rho_{0} f}{g^{2} \Delta \rho^{2}}\right)^{1 / 3}$

$M=\left(\frac{A^{2} \epsilon^{2}}{g 2 \rho_{0} f \Delta \rho}\right)^{1 / 3}$

where $f$ is the Coriolis parameter, $g$ the acceleration of gravity, and $\rho_{0}=1000 \mathrm{~kg} \mathrm{~m}^{-3}$ a constant reference density. The density difference is given by

$\Delta \rho=\beta \rho_{0} \Delta S-\Delta \rho_{\mathrm{T}}$

where $\beta$ is the haline expansion coefficient and $\Delta \rho_{\mathrm{T}}$ is the thermal density difference between waters in the cold halocline and the Atlantic layer. Eqs. (A.1)-(A.4) show that the halocline depth increases with the energy input from the wind to the vertical mixing $\epsilon$, whereas it decreases with the density difference, i.e. a smaller density difference is associated with a deeper halocline. Fig. A1 shows how the halocline depth, salinity difference, and the volume transport in the two-layer model depend on the freshwater input to the Arctic Ocean. The results are obtained using present-day conditions in the Arctic; i.e. $A \approx 9 \times 10^{12} \mathrm{~m}^{2}$, $\epsilon \approx 10^{-3} \mathrm{~W} \mathrm{~m}^{-2}$, and $\Delta \rho_{\mathrm{T}} \approx 0.2 \mathrm{~kg} \mathrm{~m}^{-3}$ (values are from (Jakobsson, 2002; Stigebrandt, 1981). The present-day freshwater input to the Arctic is about $0.28 \mathrm{~Sv}$ of which 0.09 exits through the Canadian Archipelago (Dickson et al., 2007). For a Fram Strait liquid freshwater (excluding ice) export of about $0.2 \mathrm{~Sv}$, the two-layer model yields roughly a halocline depth of $200 \mathrm{~m}$, a salinity difference of 2.5 , and a volume transport of $3 \mathrm{~Sv}$; numbers that are consistent with observations (Rudels, 1995). Note that the halocline depth increases sharply as the freshwater supply decreases below about $0.1 \mathrm{~Sv}$ with the present choice of parameters. In a cold climate, the freshwater input to the Arctic Ocean is decreased by a general decline of the hydrological cycle (Held and Soden, 2006) and presumably also due to enhanced freshwater transport carried by sea ice. Thus, the present model supports the notion of a much deeper cold halocline in glacial climates. Even if the halocline would extend below the Greenland-Scotland Ridge (about $600 \mathrm{~m}$ below the surface), the present model would still give a qualitative description of the halocline depth. It is conceivable that the Atlantic layer would be warmer in glacial periods as further equatorward sea ice cover curtails surface heat loss. This would imply a larger thermal density difference $\Delta \rho_{\text {T }}$, which also acts to deepen the cold halocline. 
a

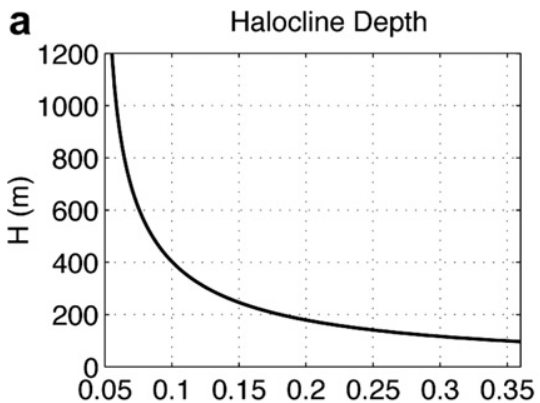

C

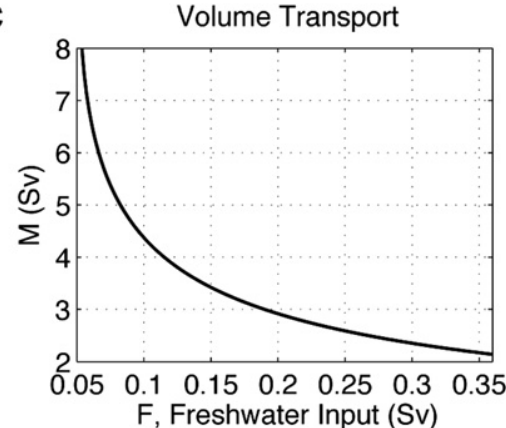

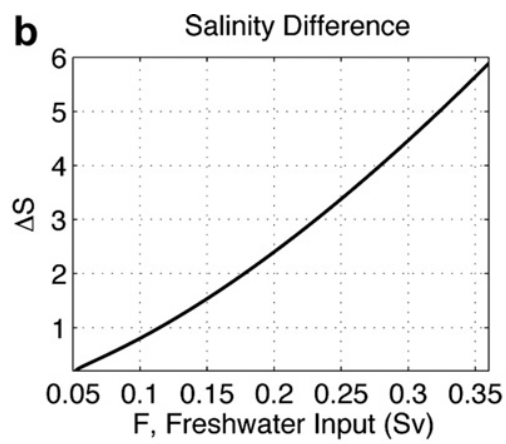
Fig. A1. Solutions of the two-layer model as a function of the freshwater input F. Panel a shows the depth of the cold halocline, roughly corresponding to the depth of the 34.5
isohaline surface within the present-day Polar Surface Water. Panel b shows the salinity difference between the Atlantic water and the halocline water. Panel c shows the export of low salinity halocline water from the Arctic to the Atlantic. Note that the model does not include sea ice formation and convection on the continental shelf, which is essential for the stratification below the Atlantic layer in the Arctic but to the lowest order of approximation negligible for the dynamics of the cold halocline.

\section{References}

Adler, R.E., Polyak, L., Ortiz, J.D., Kaufman, D.S., Channell, J.E.T., Xuan, C., Grottoli, A.G., Sellén, E., Crawford, K.A., 2009. Sediment record from the western Arctic Ocean with an improved Late Quaternary age resolution HOTRAX core HLY0503-8JPC, Mendeleev Ridge. Global and Planetary Change $68,18-29$.

Anderson, J.B., 1999. Antarctic Marine Geology. Cambridge University Press, Cambridge.

Backman, J., Fornaciari, E., Rio, D., 2009. Biochronology and paleoceanography of late Pleistocene and Holocene calcareous nannofossils across the Arctic Basin. Marine Micropaleontology 72, 86-98.

Backman, J., Shackleton, N.J., 1983. Quantitative biochronology of Pliocene and Pleistocene calcareous nannofossils from the Atlantic, Indian and Pacific ocean Marine Micropaleontology 8, 141-170.

Bentley, C.R., 1987. Antarctic ice streams: a review. Journal of Geophysical Research 92B, 8843-8858.

Boström, K., Thiede, J., 1984. YMER-80 Swedish Arctic Expedition, Cruise Report for Marine Geology and Geophysics. Meddelanden från Stockholms Universitetets Geologiska Institution, Geologiska Institutionen, Stockholm, pp. 1-123.

British Antarctic Survey, 2005. Antarctic Factsheet: Geographical Statistics. British Antarctic Survey, Cambridge.

Broecker, W.S., 1975. Floating glacial ice caps in Arctic Ocean. Science 188 $1116-1118$.

Clark, C.D., 1993. Mega-scale glacial lineations and cross-cutting ice-flow landforms. Earth Surface Processes and Landforms 18, 1-29. doi:10.1002 esp.3290180102.

Colleoni, F., 2009. On the Late Saalian Glaciation (160-140 ka) - A Climate Modeling Study. Stockholm University/Université Joseph Fourier.

Colleoni, F., Krinner, G., Jakobsson, M., The role of an Arctic ice shelf in the climate of the last glacial maximum of MIS 6 (140 ka). Ouaternary Science Reviews, submitted fro publication.

Darby, D.A., Polyak, L., Jakobsson, M., 2009. The 2005 HOTRAX expedition to the Arctic Ocean. Global and Planetary Change 68, 1-4.

Darby, D.A. Zimmerman, P., 2008. Ice-rafted detritus events in the arctic during the last glacial interval and the timing of the Innuitian and Laurentide ice sheet calving events. Polar Research 27, 114-127.

Dickson, B., Rudels, B., Dye, S., Karcher, M., Meincke, J., Yashayaev, I., 2007. Current estimates of the freshwater flux through Arctic and subarctic seas. Progress in Oceanography 73, 210-230.

Dowdeswell, J.A., Jakobsson, M., Hogan, K.A., O’Regan, M., Antony, D., Backman, J., Darby, D., Eriksson, B., Evans, D.J.A., Hell, B., Janzen, T., Löwemark, L., Marcussen, C., Noormets, R., Ó Cofaig, C., Polyak, L., Sellén, E., Sölvsten, M., High-resolution geophysical observations from the Yermak Plateau and northern Svalbard margin: implications for ice-sheet grounding and deep-keeled icebergs. Quaternary Science Reviews, submitted for publication.

Dowdeswell, J.A., Jeffries, M.O., Arctic ice shelves and ice islands: an introduction. In: Copland, L.A.M., (Ed.) Arctic Ice Shelves and Ice Islands. Springer-Verlag, Berlin, Heidelberg, NewYork, in press.

Dowdeswell, J.A., Ó Cofaig, C., Pudsey, C.J., 2004. Thickness and extent of the subglacial till layer beneath an Antarctic paleo-ice stream. Geology 32, 13-16.

Dyke, A.S., Andrews, J.T., Clark, P.U., England, J.H., Miller, G.H., Shaw, J., Veillette, J.J. 2002. The Laurentide and Innuitian ice sheets during the last glacial maximum. Quaternary Science Reviews 21, 9-31.

Engels, J.L., Edwards, M.H., Polyak, L., Johnson, P.D., 2007. Seafloor evidence for ice shelf flow across the Alaska-Beaufort margin of the Arctic Ocean. Earth Surface Processes and Landforms 32,1-17.

England, J.H., Furze, M.F.A., Doupe', J.P., 2009. Revision of the NW Laurentide Ice Sheet: implications for paleoclimate, the northeast extremity of Beringia, and Arctic Ocean sedimentation. Quaternary Science Reviews 28, 1573-1596.

Fricker, H.A., Popov, S., Allison, I., Young, N., 2001. Distribution of marine ice beneath the Amery Ice Shelf. Geophysical Research Letters 28, 2241-2244.

Grosswald, M.G., 1988. An Antarctic-style ice sheet in the northern hemisphere: towards new global glacial theory. Polar Geography and Geology 12, 239-267.

Grosswald, M.G., Hughes, T.J., 2008. The case for an ice shelf in the Pleistocene Arctic Ocean. Polar Geography 31, 69-78.

Hebbeln, D., Wefer, G., 1997. Late Quaternary paleoceanography in the Fram Strait. Paleoceanography 12, 65-78.

Held, I.M., Soden, B.J., 2006. Robust response of the hydroligical cycle to global warming. Journal of Climate 19, 5686-5699.

Heroy, D.C., Anderson, J.B., 2005. Ice-sheet extent of the Antarctic Peninsula region during the Last Glacial Maximum (LGM) -insights from glacial geomorphology. Gelogical Society of America Bulletin 117, 1497-1512.

Hughes, T.J., Denton, G.H., Grosswald, M.G., 1977. Was there a late-Würm Arctic ice sheet? Nature 266, 596-602.

Jakobsson, M., 1999. First high-resolution chirp sonar profiles from the centra Arctic Ocean reveal erosion of Lomonsov Ridge sediments. Marine Geology 158, 111-123.

Jakobsson, M., 2002. Hypsometry and volume of the Arctic Ocean and its constituent seas. Geochemistry, Geophysics, Geosystems 3, 1-18.

Jakobsson, M., Gardner, J.V., Vogt, P., Mayer, L.A., Armstrong, A., Backman, J. Brennan, R., Calder, B., Hall, J.K., Kraft, B., 2005. Multibeam bathymetric and sediment profiler evidence for ice grounding on the Chukchi Borderland, Arctic Ocean, Arctic Ocean. Quaternary Research 63, 150-160.

Jakobsson, M., Løvlie, R., Al-Hanbali, H., Arnold, E., Backman, J., Mörth, M., 2000. Manganese and color cycles in Arctic Ocean sediments constrain Pleistocene chronology. Geology 28, 23-26.

Jakobsson, M., Løvlie, R., Arnold, E.M., Backman, J., Polyak, L., Knutsen, J.-O. Musatov, E., 2001. Pleistocene stratigraphy and paleoenvironmental variation 
from Lomonosov Ridge sediments, central Arctic Ocean. Global and Planetary change $31,1-22$.

Jakobsson, M., Macnab, R., Mayer, L., Anderson, R., Edwards, M., Hatzky, J., Schenke, H.W., Johnson, P., 2008a. An improved bathymetric portrayal of the Arctic Ocean: Implications for ocean modeling and geological, geophysical and oceanographic analyses. Geophysical Research Letters 35, L07602.

Jakobsson, M., Polyak, L., Edwards, M., Kleman, J., Coakley, B., 2008b. Glacial geomorphology of the Central Arctic Ocean: the Chukchi Borderland and the Lomonosov Ridge. Earth Surface Processes and Landforms 33, 526-545.

Jakobsson, M., Marcussen, C., Lomrog, S.P., 2008c. Lomonosov ridge off Greenland 2007 (LOMROG) - cruise report. Special Publication Geological Survey of Denmark and Greenland. Geological Survey of Denmark and Greenland, Copenhagen, pp. 122.

Jeffries, M.O., 1986. Ice Island calvings and ice shelf changes, Milne Ice Shelf and Ayles Ice Shelf, Ellesmere Island. N.W.T. Arctic 39, 15-19.

Jokat, W., 1999. ARCTIC '98: The Expedition ARK-XIVIl a of RV “Polarstern" in 1998, Berichte zur Polarforschung. Alfred Wegener Institute for Polar and Marine Research (AWI), Bremerhaven, pp. 172.

Joughin, I., MacAyeal, D.R., 2005. Calving of large tabular icebergs from ice shelf rift systems. Geophysical Research Letters 32, L02501.

Kato, H., Phillips, O.M., 1969. On the penetration of a turbulent layer into a stratified fluid. Journal of Fluid Mechanics 37, 643-655.

Knies, J., Kleiber, H.P., Matthiessen, J., Muller, C., Nowaczyk, N., 2001. Marine Icerafted Debris Records Constrain Maximum Extent of Saalian and Weichselian Ice-sheets Along the Northern Eurasian Margin. Elsevier Science Bv, pp. 45-64.

Knies, J., Nowaczyk, N., Muller, C., Vogt, C., Stein, R., 2000. A multiproxy approach to reconstruct the environmental changes along the Eurasian continental margin over the last 150,000 years. Marine Geology 163, 317-344.

Knies, J., Stein, R., 1999. New aspects of organic carbon deposition and its paleoceanographic implications along the northern Barents Sea margin during the last 30,000 years (vol. 13, pg 384, 1998). Paleoceanography 14, 233.

Kristoffersen, Y., Coakley, B., Jokat, W., Edwards, M., Brekke, H., Gjengedal, J., 2004. Seabed erosion on the Lomonosov Ridge, central Arctic Ocean: a tale of deep draft icebergs in the Eurasia Basin and the influence of Atlantic water inflow on iceberg motion? Paleoceanography 19, PA3006.

Lloyd, J.M., Kroon, D., Boulton, G.S., Laban, C., Fallick, A., 1996. Ice rafting history from the Spitsbergen ice cap over the last 200 kyr. Marine Geology 131, 103-121.

Löwemark, L., Werner, F., 2001. Dating errors in high-resolution stratigraphy: a detailed X-ray radiograph and AMS-C-14 study of Zoophycos burrows. Marine Geology 177, 191-198.

Lythe, M.B., Vaughan, D.G., Consortium, B., 2001. BEDMAP: a new ice thickness and subglacial topographic model of Antarctica. Journal of Geophysical Research 106, 11335-11352.

Maslowski, W., Marble, D., Walczowski, W., Schauer, U., Clement, J.L., Semtner, A.J., 2004. On climatological mass, heat, and salt transports through the Barents Sea and Fram Strait from a pan-Arctic coupled ice-ocean model simulation. Journal of Geophysical Research 109.

Matthiessen, J., Knies, J., 2001. Dinoflagellate cyst evidence for warm interglacial conditions at the northern Barents Sea margin during marine oxygen isotope stage 5. Journal of Quaternary Science 16, 727-737.

Mercer, J.H., 1970. A former ice sheet in the Arctic Ocean? Palaeogeography, Palaeoclimatology, Palaeoecology 8, 19-27.

Nilsson, J., Wallin, G., 2010. Salinity-dominated thermohaline circulation in sill basins: can two stable equilibria exist? Tellus A 62 (2), 123-133. doi:10.1111/ j.1600-0870.2009.00428.x.

Nøst, O.A., Nilsson, J., Nycander, J., 2008. On the asymmetry between cyclonic and anticyclonic flow in basins with sloping boundaries. Journal of Physical Oceanography $38,771-787$.
O'Regan, M., Jakobsson, M., Kirchner, N., Glacial geological implications of overconsolidated sediments on the Lomonosov Ridge and Yermak Plateau, submitted for publication.

Polyak, L., Bischof, J., Ortiz, J., Darby, D., Channell, J., Xuan, C., Kaufman, D., Lovlie, R., Schneider, D., Adler, R., 2009. Late Quaternary stratigraphy and sedimentation patterns in the western Arctic Ocean. Global and Planetary Change 68, 5-17.

Polyak, L., Darby, D., Bischof, J., Jakobsson, M., 2007. Stratigraphic constraints on late Pleistocene glacial erosion and deglaciation of the Chukchi margin, Arctic Ocean. Quaternary Research 67, 234-245.

Polyak, L., Edwards, M.H., Coakley, B.J., Jakobsson, M., 2001. Ice shelves in the Pleistocene Arctic Ocean inferred from glaciogenic deep-sea bedforms. Nature 410, 453-459.

Rabineau, M., Berné, S., Olivet, J.-L., Aslanian, D., Guillocheau, F., Joseph, P., 2006. Paleo sea levels reconsidered from direct observation of paleoshoreline position during Glacial Maxima (for the last 500,000 yr). Earth and Planetary Science Letters 252, 119-137.

Rudels, B., 1995. The thermohaline circulation of the Artic Ocean and the Greenland Sea. Philosophical Transactions: Physical Sciences and Engineering 352, 287-299.

Rudels, B., Anderson, L., Eriksson, P., Fahrbach, E., Jakobsson, M., Jones, P., Melling, H., Prinsenberg, S., Schauer, U., Yao, T., Observations in the ocean. In: Lemke, P., Arctic Climate System Study (ACSYS), in press.

Shipoard Scientific Party, 1995. Site 910. In: Myhre, A.M., Thiede, J., Firth, J.V. (Eds.), Proceedings of the Ocean Drilling Programs, Initial Reports. Ocean Drilling Program, Texas, pp. 221-270.

Shipp, S., Anderson, J.B., Domack, E.W., 1999. Late Pleistocene-Holocene retreat of the West Antarctic ice-sheet system in the Ross Sea; Part 1. Geophysical results Geological Society of America Bulletin 111, 1468-1516.

Spielhagen, R.F., Baumann, K.H., Erlenkeuser, H., Nowaczyk, N.R., NorgaardPedersen, N., Vogt, C., Weiel, D., 2004. Arctic Ocean deep-sea record of northern Eurasian ice sheet history. Quaternary Science Reviews 23, 1455-1483.

Stein, R., Matthiessen, J., Niessen, F., Krylov, A., Seung-il, N., Bazhenova, E., The Shipboard Geology Group, Towards a better (litho-) stratigraphy and reconstruction of Quaternary paleoenvironment in the Amerasian Basin (Arctic Ocean). Polarforschung, in press.

Stigebrandt, A., 1981. A model for the thickness and salinity of the upper layer in the Arctic Ocean and the relationship between the ice thickness and some external parameters. Journal of Physical Oceanography 11, 1407-1422.

Svendsen, J.I., Alexanderson, H., Astakhov, V.I., Demidov, I., Dowdeswell, J.A., Henriksen, M., Hjort, C., Houmark-Nielsen, M., Hubberten, H.W., Ingólfson, O., Jakobsson, M., Kjær, K., Larsen, E., Lokrantz, H., Lunkka, J.P., Lyså, A., Mangerud, J., Maslenikova, O., Matioushkov, A., Murray, A., Möller, P., Niessen, F., Saarnisto, M., Siegert, C., Stein, R., Siegert, M.J., Spielhagen, R., 2004. Late Quaternary ice sheet history of northern Eurasia. Quaternary Science Reviews 23, 1229-1271.

Vogt, P.R., Crane, K., Sundvor, E., 1994. 1994. Deep Pleistocene iceberg plowmarks on the Yermak Plateau: sidescan and $3.5 \mathrm{kHz}$ evidence for thick calving ice fronts and a possible marine ice sheet in the Arctic Ocean. Geology 22, 403-406.

Wåhlin, A.K., Björk, G., Nohr, C., Yuan, X. Inflow of warm Circumpolar Deep Water in the Central Amundsen Shelf Sea. Journal of Physical Oceanography. in press, doi:10.1175/2010JPO4431.1.

Walker, D.P., Brandon, M.A., Jenkins, A., Allen, J.T., Dowdeswell, J.A., Evans, J., 2007. Oceanic heat transport onto the Amundsen Sea shelf through a submarine glacial trough. Geophysical Research Letters 34.

Williams, M., Dowdeswell, J.A., 2001. Historical fluctuations of the Matusevich Ice Shelf, Severnaya Zemlya, Russian High Arctic. Arctic. Antarctic and Alpine Research 33, 211-222.

Woodgate, R.A., Aagaard, K., 2005. Revising the Bering Strait freshwater flux into the Arctic Ocean. Geophysical Research Letters 32. 